\title{
AN AERIAL RADIOLOGICAL SURVEY OF THE YUCCA MOUNTAIN PROJECT PROPOSED LAND WITHDRAWAL AND ADJACENT AREAS
}

\author{
NYE COUNTY, NEVADA
}

\author{
Craig Lyons \\ Thane Hendricks \\ National Security Technologies, LLC \\ Las Vegas, Nevada
}

SURVEY DATES - January 25 to April 19, 2006

Prepared for the U.S. Department of Energy, National Nuclear Security Administration Nevada Site Office Work performed by Bechtel Nevada under Contract Number DE-AC08-96NV11718. Work performed by National Security Technologies, LLC, under Contract Number DE-AC52-06NA25946. 


\section{DISCLAIMER}

This work was prepared as an account of work sponsored by an agency of the United States Government. Neither the United States Government nor any agency thereof, nor any of their employees, nor any of their contractors, subcontractors or their employees, makes any warranty, express or implied, or assumes any legal liability or responsibility for the accuracy, completeness, or any third party's use or the results of such use of any information, apparatus, product, or process disclosed, or represents that its use would not infringe privately owned rights. Reference herein to any specific commercial product, process, or service by trade name, trademark, manufacturer, or otherwise, does not necessarily constitute or imply its endorsement, recommendation, or favoring by the United States Government or any agency thereof or its contractors or subcontractors. The views and opinions of authors expressed herein do not necessarily state or reflect those of the United States Government or any agency thereof.

Available for sale to the public from-

U.S. Department of Commerce

National Technical Information Service

5285 Port Royal Road

Springfield, VA 22161

Phone: 800-553-6847

Fax: 703-605-6900

E-mail: orders@ntis.gov

Online ordering: http://www.ntis.gov/ordering.htm

Available electronically at http://www.osti.gov/bridge

Available for a processing fee to U.S. Department of Energy and its contractors, in paper from-

U.S. Department of Energy

Office of Scientific and Technical Information

P.O. Box 62

Oak Ridge, TN 37831-0062

Phone: (865) 576-8401

Fax: (865) 576-5728

E-mail: reports@adonis.osti.gov 
An aerial radiological survey of the Yucca Mountain Project (YMP) proposed land withdrawal was conducted from January to April 2006, and encompassed a total area of approximately 284 square miles (73,556 hectares). The aerial radiological survey was conducted to provide a sound technical basis and rigorous statistical approach for determining the potential presence of radiological contaminants in the Yucca Mountain proposed Land withdrawal area. The survey site included land areas currently managed by the Bureau of Land Management, the U.S. Air Force as part of the Nevada Test and Training Range or the U.S. Department of Energy (DOE), National Nuclear Security Administration Nevada Site Office (NNSA/NSO) as part of the Nevada Test Site (NTS). The survey was flown at an approximate ground speed of 70 knots (36 meters per second), at a nominal altitude of $150 \mathrm{ft}(46 \mathrm{~m})$ above ground level, along a set of parallel flight lines spaced $250 \mathrm{ft}(76 \mathrm{~m})$ apart. The flight lines were oriented in a north-south trajectory.

The survey was conducted by the DOE NNSA/NSO Remote Sensing Laboratory-Nellis, which is located in Las Vegas, Nevada. The aerial survey was conducted at the request of the DOE Office of Civilian Radioactive Waste Management.

The primary contaminant of concern was identified by YMP personnel as cesium-137 $\left({ }^{137} \mathrm{Cs}\right)$. Due to the proposed land withdrawal area's proximity to the historical Nuclear Rocket Development Station (NRDS) facilities located on the NTS, the aerial survey system required sufficient sensitivity to discriminate between dispersed but elevated ${ }^{137} \mathrm{Cs}$ levels from those normally encountered from worldwide fallout. As part of that process, the survey also measured and mapped the exposure-rate levels that currently existed within the survey area. The inferred aerial exposure rates of the natural terrestrial background radiation varied from less than 3 to 22 microroentgens per hour. This range of exposure rates was primarily due to the surface geological features within the survey area. The survey area has extensive areas of desert valleys, mountain ranges, extinct volcanic cones, and old lava flows.

With the exception of five areas identified within the NRDS boundaries (discussed later in this report), there were no areas within the survey that exceeded aerial survey minimum detectable concentration levels of 0.4 through 0.7 picocuries per gram $(\mathrm{pCi} / \mathrm{g})$. The ${ }^{137} \mathrm{Cs}$ levels do not exceed typical worldwide fallout levels for the continental United States. 


\section{TABLE OF CONTENTS}

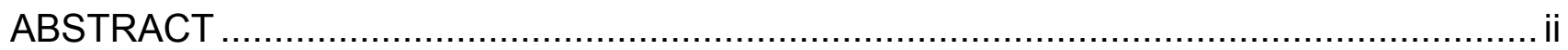

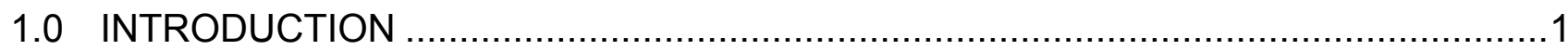

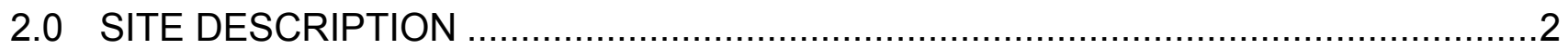

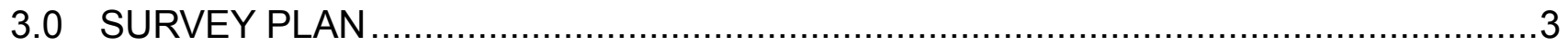

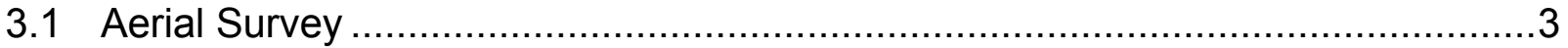

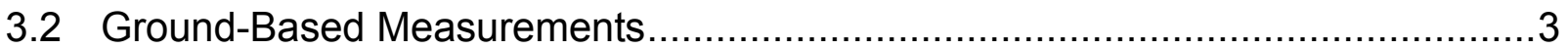

3.2.1 Calibration Measurements at Lake Mohave ........................................

3.2.2 Soils Measurements Made in Yucca Survey Area ....................................3

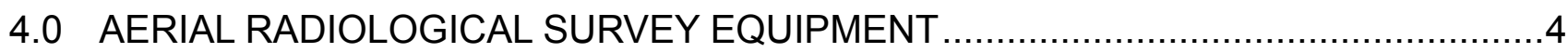

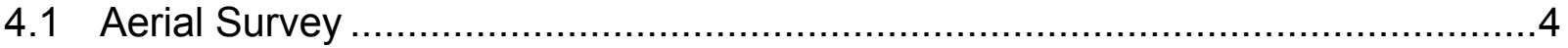

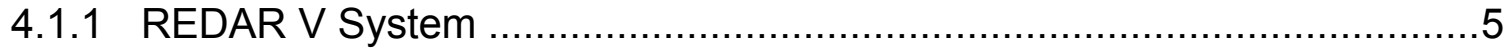

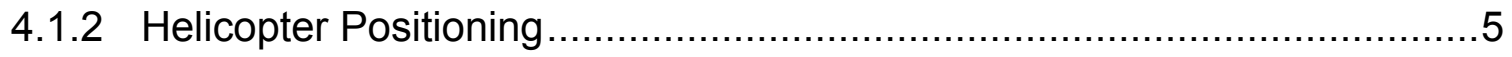

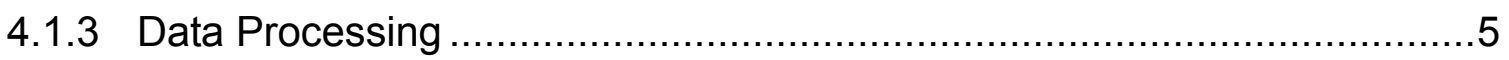

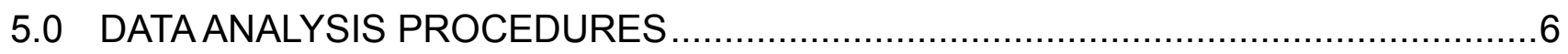

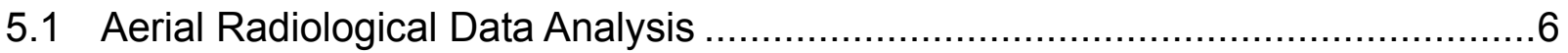

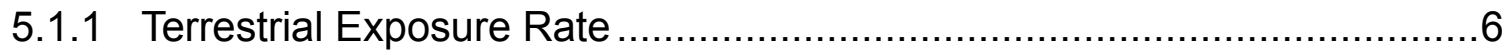

5.1.2 Man-Made Gross Count ..........................................................

5.1.3 Three-Window Isotopic Extraction Algorithm ....................................

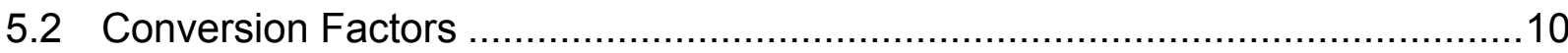

5.3 Minimum Detectable Concentration.......................................................... 13

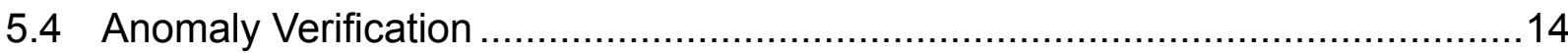

6.0 RESULTS

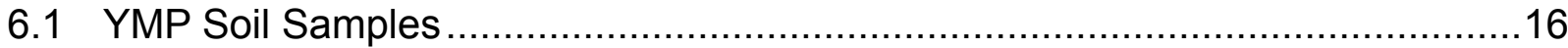

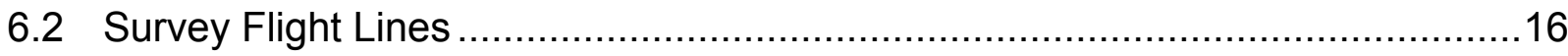

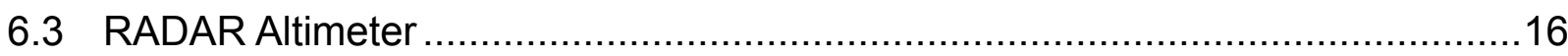

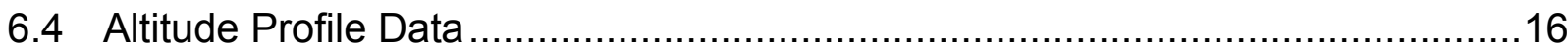

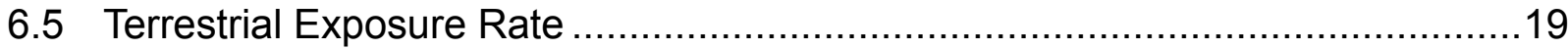

6.6 Terrestrial Exposure with Serpentine Normalization Layer .............................19

6.7 Minimum Detectable Concentrations Illustrations .........................................19

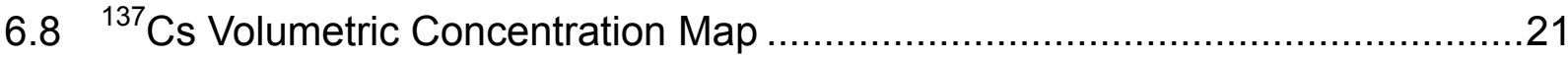


$6.9{ }^{137}$ Cs Minimum Detectable Volumetric Concentration......................................22

6.10 Typical Survey Spectra from Background Areas ...........................................22

6.11 Areas Where Cesium-137 Was Detected ……..........................................23

6.11 Cesium-137 Extraction Over Test Cell C …..................................................23

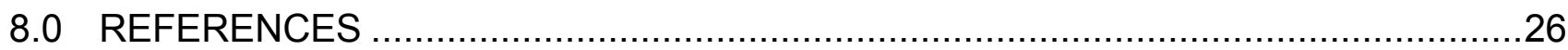

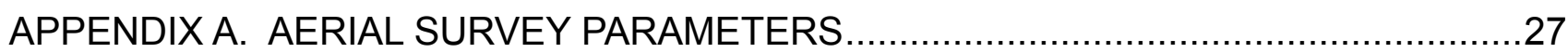

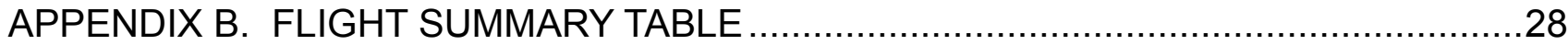

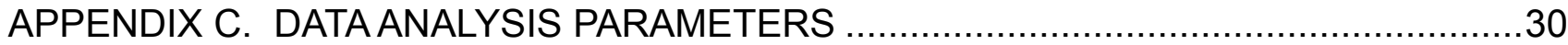




\section{LIST OF FIGURES}

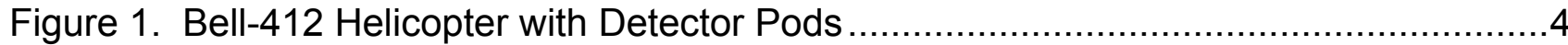

Figure 2. General Three-Window Region of Interest Selection ......................................

Figure 3. ${ }^{137} \mathrm{Cs}$ Minimum Detectable Volumetric Concentration (MDC) ............................32

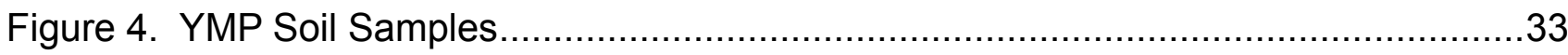

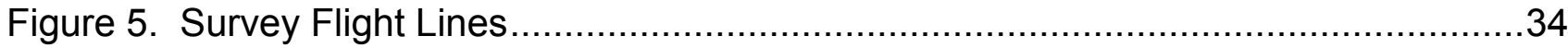

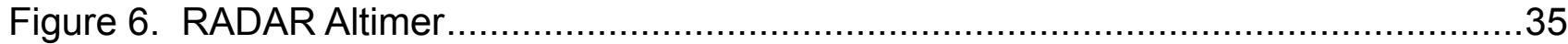

Figure 7. Altitude Profile Data, Uncorrected for Background and Altitude ........................18

Figure 8. Altitude Profile Data, Corrected for Background and Altitude ............................18

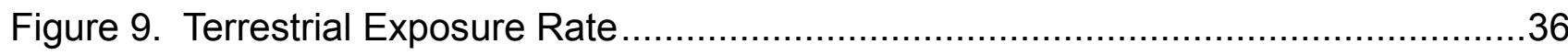

Figure 10. Terrestrial Exposure Rate with Serpentine Normalization Layer …...................37

Figure 11. Line Segment from YMP Survey over ID $=\# 5{ }^{137}$ Cs Area ..............................20

Figure 12. Distributions of $\mathrm{pCi} / \mathrm{g}$ and MDC Values. YMP Full Survey .............................20

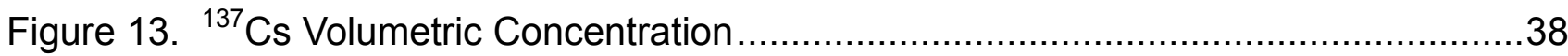

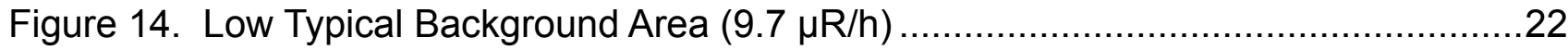

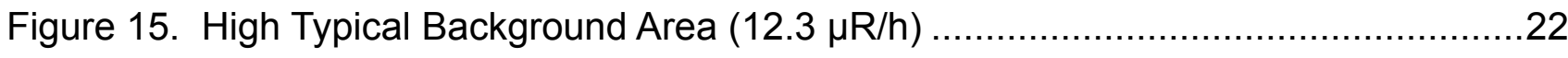

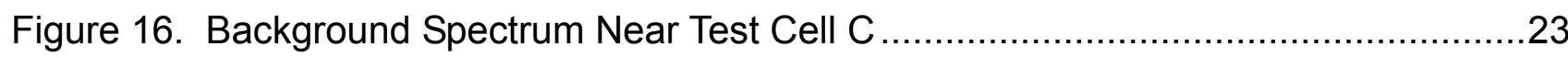

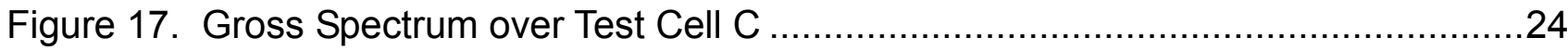

Figure 18. Net Spectrum over Test Cell C (Figure 17 Gross Minus Figure 9 Background).24

\section{LIST OF TABLES}

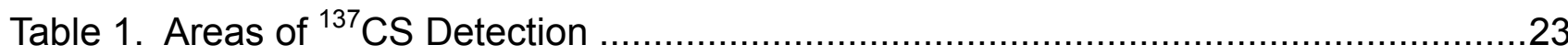




\section{ACRONYMS, ABBREVIATIONS, AND SYMBOLS}

$\begin{array}{ll}\mu \mathrm{R} / \mathrm{h} & \text { microroentgens per hour (a unit of exposure rate) } \\ { }^{241} \mathrm{Am} & \text { americium-241 } \\ { }^{214} \mathrm{Bi} & \text { bisimuth-241 } \\ { }^{137} \mathrm{Cs} & \text { cesium-137 (worldwide fallout due to atmospheric weapons testing) } \\ { }^{40} \mathrm{~K} & \text { potassium-40 (radioactive potassium) } \\ { }^{234} \mathrm{Th} & \text { thorium-234 (part of the uranium decay chain) } \\ { }^{234} \mathrm{U} & \text { uranium-234 (part of the uranium decay chain) } \\ { }^{235} \mathrm{U} & \text { uranium-235 (fissile component of natural uranium) } \\ \mathrm{AGL} & \text { above ground level } \\ \mathrm{AMS} & \text { Aerial Measuring System } \\ \mathrm{BKG} & \text { background } \\ \mathrm{BN} & \text { Bechtel Nevada } \\ \mathrm{BREN} & \text { Bare Reactor Experiment-Nevada } \\ \mathrm{C} & \text { Centigrade } \\ \mathrm{cm} & \text { centimeter(s) } \\ \mathrm{cm}{ }^{2} & \text { square centimeters } \\ \mathrm{cps} & \text { counts per second } \\ \mathrm{DGPS} & \text { Differential Global Positioning System } \\ \mathrm{DOE} & \text { U.S. Department of Energy } \\ \mathrm{DRA} & \text { Desert Rock Airport } \\ \mathrm{ft} & \text { foot (feet) } \\ \mathrm{ft}^{-1} & \text { per feet (1/ft) } \\ \mathrm{ft}^{2} & \text { square feet } \\ \mathrm{FOV} & \text { field of view } \\ \mathrm{g} / \mathrm{cm}{ }^{2} & \text { grams per square centimeter } \\ \mathrm{g} / \mathrm{cm}{ }^{3} & \text { gram(s) per cubic centimeter } \\ \mathrm{GPS} & \text { Global Positioning System } \\ \mathrm{in} . & \text { inch(es } \\ \mathrm{keV} & \text { kiloelectron volt(s) } \\ \mathrm{m} & \text { meter(s) } \\ \mathrm{m}^{-1} & \text { per meter (1/m) } \\ & \end{array}$




\section{ACRONYMS, ABBREVIATIONS, AND SYMBOLS (Continued)}

\begin{tabular}{ll}
\hline $\mathrm{m}^{2}$ & square meters \\
$\mathrm{m} / \mathrm{s}$ & meter(s) per second \\
$\mathrm{MCA}$ & multichannel analyzer \\
MDC & minimum detectable concentration \\
$\mathrm{mi}$ & mile(s) \\
MMGC & man-made gross count \\
$\mathrm{mph}$ & mile(s) per hour \\
MSL & mean sea level \\
Nal (TI) & thallium-activated, sodium iodide gamma ray scintillation detector \\
NNSA/NSO & U.S. Department of Energy, National Nuclear Security Administration Nevada \\
& Site Office \\
NRDS & Nuclear Rocket Development Station \\
NTS & Nevada Test Site \\
OCRWM & Office of Civilian Radioactive Waste Management \\
pCi/g & picocurie(s) per gram (a unit of soil concentration) \\
RDGPS & Real-time Differential Global Positioning System \\
REDAR V & Radiation and Environmental Data Acquisition and Recorder, Version V \\
RMSF & Radioactive material Storage Facility \\
RSL-N & Remote Sensing Laboratory-Nellis \\
USGS & U.S. Geological Survey \\
YMP & Yucca Mountain Project
\end{tabular}




\section{$1.0 \quad$ INTRODUCTION}

An aerial radiological survey of the Yucca Mountain Project (YMP) proposed land withdrawal was conducted from January to April 2006. The survey encompassed a total area of approximately 284 square miles (73,556 hectares). The survey was conducted by the U.S. Department of Energy (DOE), National Nuclear Security Administration Nevada Site Office's (NNSA/NSO) Remote Sensing Laboratory (RSL-N), located in Las Vegas, Nevada The survey was conducted at the request of the DOE Office of Civilian Radioactive Waste Management (OCRWM), which is responsible for the YMP.

The primary objective of the survey was to provide data that provided a sound technical basis and rigorous statistical approach for determining the presence of man-made radiological contaminants within the proposed land withdrawal area. The primary contaminant of concern was identified as cesium-137 ( $\left.{ }^{137} \mathrm{Cs}\right)$. As part of that verification process, the aerial survey was conducted to measure and map the natural and man-made gamma radiation within, and surrounding, the YMP proposed land withdrawal. With the concurrence of the BN Environmental Restoration Project, adjacent Nuclear Rocket Development Station (NRDS) facilities are included in this survey report due to their potential as emitters of man-made radionuclides (primarily ${ }^{137} \mathrm{Cs}$ ) during past operations.

Results are reported as radiation isopleths superimposed on U.S. Geological Survey (USGS) maps of the survey area. In addition, satellite imagery (WGS-84 datum) was provided to RSL-N through its Geographical Information System group for interim mapping and anomaly investigation purposes. Areas of elevated levels of terrestrial exposure rate and specific isotopic ${ }^{137} \mathrm{Cs}$ gamma radiation activity are reported. 


\subsection{SITE DESCRIPTION}

The YMP is a DOE-owned site operated by the Bechtel SAIC Company, LLC. The YMP proposed land withdrawal area and adjacent areas are sparsely populated. The final land withdrawal will be mandated by the United States Congress and will be controlled under the OCRWM. Elevations of the surveyed area ranged between 2,500 and 6,600 feet ( $\mathrm{ft}$ ) (762 and 2,012 meters [m]) above mean sea level (MSL). 


\subsection{SURVEY PLAN}

\subsection{Aerial Survey}

The aerial radiological survey area included the YMP proposed land withdrawal area and priority roads. The area was surveyed by a Bell-412 twin-engine helicopter flying at a nominal ground speed of 70 knots (36 meters per second [m/s]), at a nominal altitude of $150 \mathrm{ft}(46 \mathrm{~m})$ above ground level (AGL), and along a set of parallel flight lines spaced $250 \mathrm{ft}$ $(76 \mathrm{~m})$ apart. Flight lines were oriented and flown in either a north or south direction (nominally parallel to the rugged terrain features). Details of the aerial survey parameters are presented in Appendix A.

To ensure data integrity and to monitor and correct variations in the detector's background radiation due to radon, cosmic rays, and the aircraft, repeated measurements were made over a land test-line at the beginning and end of each flight. The land test-line was located between the Desert Rock Airport (DRA) facility and the US 95 highway. The test-line was a gravel road leading from the DRA area to a water well adjacent to the highway. The test line was flown visually.

In addition to the test lines, a "serpentine flight" was conducted in which a line segment from each completed flight was flown during a single flight to further validate the background and normalization process. A summary of the number of flights and number of lines flown is presented in Appendix B.

\subsection{Ground-Based Measurements}

\subsubsection{Calibration Measurements at Lake Mohave}

The helicopter/detector system has been flown over a calibrated test range at Lake Mohave to determine the nominal calibration coefficient (counts/second at altitude per microRoentgen per hour $[\mu \mathrm{R} / \mathrm{h}]$ at $1 \mathrm{~m}$ above the ground) for the system. Exposure rate calibrations used for processing of the Yucca survey are based on these Lake Mohave measurements.

\subsubsection{Soils Measurements Made in Yucca Survey Area}

Soils measurements made in the YMP survey area were provided to RSL-N by YMP personnel. The values were very small (small fractions of a picocurie per gram [pCi/g]), representing values typically lower than the minimum detectable concentration (MDC) that could be seen from the air. Therefore, useful correlations between soil and aerial ${ }^{137} \mathrm{Cs}$ concentrations could not be drawn. 


\subsection{AERIAL RADIOLOGICAL SURVEY EQUIPMENT}

\subsection{Aerial Survey}

Standard aerial radiological survey techniques developed for large-area gamma radiation surveys were used ${ }^{1-5}$. The survey methodology has been successfully applied to more than 500 individual surveys at various locations beginning in the late 1960s.

This aerial radiological survey was conducted using the Aerial Measuring System (AMS), which included a Bell-412 helicopter; a Radiation and Environmental Data Acquisition and Recorder, Version V (REDAR V); and a Real-time Differential Global Positioning System (RDGPS) (Figure 1). The helicopter was equipped with two large detector pods mounted on the side of the aircraft. Each pod contained six 2- x 4- x 16-inch (-in.) (5- x 10- x 41-centimeter $[\mathrm{cm}]$ ) thallium-activated sodium iodide, $\mathrm{Nal}(\mathrm{TI})$, scintillation gamma-ray detectors.

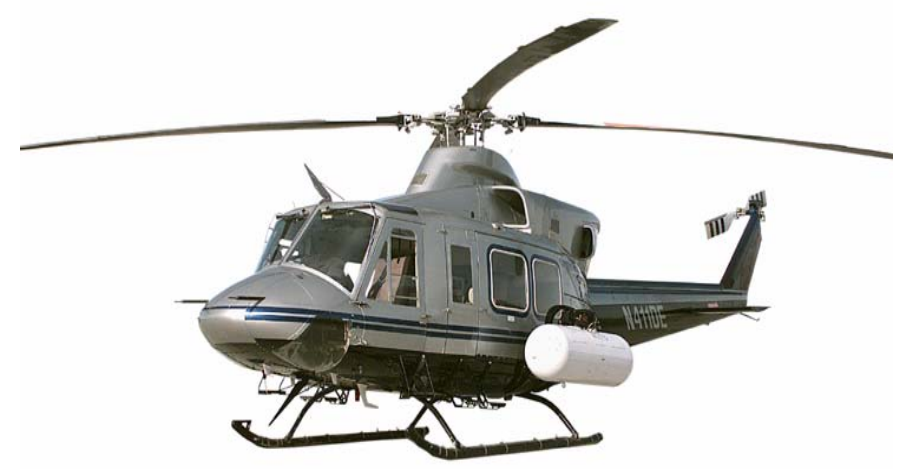

Figure 1. Bell-412 Helicopter with Detector Pods

The signal from each detector was calibrated using americium-241 $\left({ }^{241} \mathrm{Am}\right)$ gamma-check sources for the low-energy spectrum and the natural potassium- $40\left({ }^{40} \mathrm{~K}\right)$ for the high-energy spectrum peak. Normalized outputs from each of the $12 \mathrm{Nal}(\mathrm{TI})$ detectors were combined in a 12-way analog-summing amplifier. The signal was adjusted in the analog-to-digital converter so that the calibration photopeaks appeared in pre-selected channels in one of the four REDAR V multichannel analyzers (MCAs). Gain stabilization circuitry is utilized to maintain the channel to energy adjustment. The calibrated output from one of the Nal (TI) detectors was fed to an independent MCA to provide increased dynamic range for viewing potential higher-radiation areas. 


\subsubsection{REDAR V System}

Data were acquired using the REDAR $V$ system designed for use in aircraft. The REDAR V is a portable, real-time, UNIX-based multi-processor data collection instrument. The REDAR $V$ runs multiple, dedicated processors and operating systems, including four 4,096-channel MCAs, 16 analog inputs, and 6 serial input/output ports, that can gather a multitude of data. All data are acquired in 1-second increments and stored to hard drives. Typical data collected include four 1,024 channel gamma-energy spectra, spectral live time/dead time for each spectrum, ambient air temperature, absolute barometric pressure, and aircraft altitude and position. This information can be displayed in real time while in flight.

\subsubsection{Helicopter Positioning}

The position of the helicopter was established by using two systems: a RDGPS and a radar altimeter. The RDGPS is a space-based navigational system that provides continuous positional information accurate to $\pm 10 \mathrm{ft}(3 \mathrm{~m})$ using a minimum of 4 of the 24 GPS (Global Positioning System) satellites orbiting the earth. The radar altimeter determines the altitude by measuring the round-trip propagation time of a signal reflected off the ground. The accuracy of the radar altimeter is \pm 2 percent or $2 \mathrm{ft}(0.6 \mathrm{~m})$, whichever is larger.

\subsubsection{Data Processing}

The raw spectral and positional data collected and reported by the AMS were transferred at the conclusion of each flight via an Internet server from the Nevada Test Site (NTS) to the RSL-N facility. Preliminary contour maps of the terrestrial exposure rate, man-made radioactivity, ${ }^{137} \mathrm{Cs}$ soil concentration, and the survey's flight altitude were created at the RSL-N facility to verify data quality and to indicate areas where further survey work might be necessary. After the return of the survey crew to the RSL-N from the DRA at the NTS, the data were further processed, using the same type of analysis system, to produce the principal data products. 


\subsection{DATA ANALYSIS PROCEDURES}

Standard techniques were used for analyzing the survey data. Terrestrial exposure rates were computed from gross count data with a correction for variations in altitude. Activity or count-rates due to man-made radioactivity (e.g., ${ }^{137} \mathrm{Cs}$ ) were determined through differences between total counts in the appropriate gamma energy spectral windows. All necessary refinements of the data were also applied at this stage of processing. These refinements included subtraction of more accurate estimates of the background radiation, and application of more accurate altitude and dead-time corrections. Finally, contours were superimposed on a properly scaled and geo-rectified (WGS-84 datum) USGS map of the survey area. Specific information on the data analysis parameters used is listed in Appendix C.

\subsection{Aerial Radiological Data Analysis}

Aerial radiation data generally contain contributions from the naturally occurring radionuclides, man-made radionuclides, airborne radon, cosmic rays, and aircraft-induced electronic noise. For this survey, principal products of the analysis of the aerial survey data are contour maps of the terrestrial exposure rate, gross counts of the natural radioactivity, and isopleth contour maps of the soil concentrations for ${ }^{137} \mathrm{Cs}$. The basic procedures involved in constructing these products from the gamma energy spectral data are briefly reviewed in this section. More detailed information can be found in separate publications ${ }^{4,5}$.

\subsubsection{Terrestrial Exposure Rate}

The terrestrial exposure rate method is based on the integral count rate in the gamma energy spectral range between 38 and 3,026 kiloelectron volts (keV):

$$
C R_{G C}=\sum_{E=38}^{3026} S(E)-N T B
$$

where

$$
\begin{aligned}
\mathrm{CR}_{\mathrm{GC}}= & \text { terrestrial count-rate or gross count in counts per second (cps) } \\
S(E)= & \text { energy spectrum containing the number of gamma rays collected at the given } \\
& \text { energy } E \text { per second } \\
E= & \text { the photon energy in keV } \\
N T B= & \text { non-terrestrial background in cps produced by the effects of airborne radon, } \\
& \text { cosmic rays, and the aircraft background }
\end{aligned}
$$

The gross count, measured in cps at survey altitude, was converted to an exposure rate in $\mu \mathrm{R} / \mathrm{h}$ at a height of $1 \mathrm{~m} \mathrm{AGL}$ by application of a conversion factor derived (cross-calibrated) from the ground-based corroborative pressurized ionization chamber exposure rate 
measurements that were collected at the Lake Mohave calibration survey area in support of the AMS survey program over many years.

The conversion equation used is:

$$
E R=\frac{C R_{G C}}{1729} e^{(A-45.7) \mu_{\text {air }}}
$$

where

$E R=$ exposure rate extrapolated to $1 \mathrm{~m} \mathrm{AGL}$ in $\mu R / \mathrm{h}$

$A=$ survey altitude in meters

$\mu_{\text {air }}=$ gamma ray air attenuation coefficient in $\mathrm{m}^{-1}$

$1,729=$ conversion factor relating the gross count to exposure rate in $\mathrm{cps} /(\mu \mathrm{R} / \mathrm{h})$

The air attenuation coefficient, $\mu_{\text {air }}$, deduced empirically from the altitude profile data acquired over the YMP survey land test line, was $0.00174 \mathrm{ft}^{-1}\left(0.00571 \mathrm{~m}^{-1}\right)$. The derived conversion factor, obtained from the Lake Mohave ground-based exposure-rate measurements, was $1,729 \mathrm{cps}$ per $\mu \mathrm{R} / \mathrm{h}$ for a survey altitude of $150 \mathrm{ft}(46 \mathrm{~m}) \mathrm{AGL}$. The applicability of this conversion equation assumes a uniformly distributed radiation source covering an area that is large when compared to the field of view (FOV) of the detection system (a circle with a diameter roughly twice the altitude of the aircraft).

\subsubsection{Man-Made Gross Count}

The aerial data were also used to determine the location of non-naturally-occurring gamma sources (i.e., man-made radionuclides). Man-made gross count (MMGC) is the portion of the gross count which is directly attributed to the gamma rays from man-made radionuclides. Large amounts of man-made radionuclides can be found from increases in the gross count. However, slight variations in the gross count are generally not considered adequate proof to suspect the presence of a man-made anomaly since these variations can result naturally from geological fluctuations or changes in the ground coverage (e.g., rivers, vegetation, buildings).

In order to increase the sensitivity of the AMS to detect man-made anomalies, a man-made gross count algorithm has been developed that uses differential spectral energy extraction techniques to identify changes in the gamma energy spectral shapes. This algorithm takes advantage of the fact that while background radiation levels often vary by a factor of two or more within a survey area, background spectral shapes remain essentially constant. More specifically, the ratio of natural components in any two sections (windows) of the energy spectrum will remain nearly constant. 
Although this procedure can be applied to any region of the gamma energy spectrum, the most common practice is to place all counts below $1,394 \mathrm{keV}$ into the man-made window (low-energy sum), where most of the long-lived, man-made radionuclides emit radiation. All counts above $1,394 \mathrm{keV}$ are placed into the natural window (high-energy sum), where mostly the naturally-occurring radionuclides and only a few man-made radionuclides emit radiation. The MMGC rate can be expressed analytically in terms of the integrated count rates in specific gamma energy spectral windows (keV):

$$
M M G C=\sum_{E=38}^{1394} S(E)-K_{m m} * \sum_{E=1394}^{3026} S(E)
$$

where $K_{m m}$ is defined over an area that contains only gamma radiation from naturallyoccurring radionuclides as

$$
K_{m m}=\frac{\sum_{E=38}^{1394} S(E)}{\sum_{E=1394}^{3026} S(E)}
$$

This MMGC algorithm has been found to be sensitive to low levels of man-made radiation even in the presence of large variations in the natural background. Once a region of manmade radioactivity has been identified, a detailed analysis of the gamma energy spectrum is conducted to ascertain which radionuclides are present.

It should be noted that in areas where the aircraft's altitude changes significantly from the planned altitude and/or in areas exhibiting different relative concentrations of natural potassium, uranium, and/or thorium, the ratio of low-energy to high-energy gamma rays may be different even though the gamma rays are emitted by naturally occurring radionuclides. In such cases, the MMGC algorithm may generate a set of "false positive" anomalies on the MMGC contour map. A background-subtracted gamma spectrum in this case will show only natural radionuclides or a smoothly varying background with no discernable peaks.

The man-made algorithm was utilized in the quick-look quality assurance processing of the YMP radiological data. It is not presented in this report as the specific ${ }^{137}$ Cs extraction is more definitive than the generic man-made extraction for the YMP data set. 


\subsubsection{Three-Window Isotopic Extraction Algorithm}

Three-Window Algorithm Two background windows are selected, one below and one above the selected photopeak of interest such that they essentially define the beginning and end of the Compton continuum that exists below the photopeak (see Figure 2).

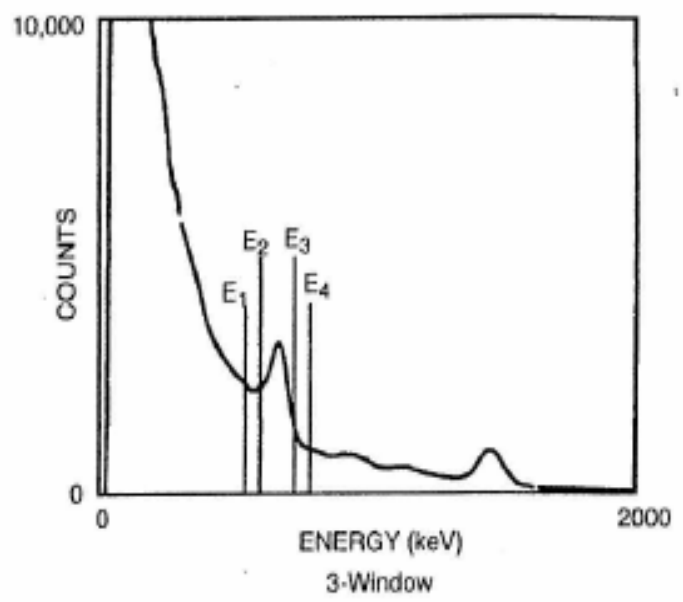

Figure 2. General Three-Window Region of Interest Selection

Referring to Figure 2,

$$
C R_{3 \text {-Window }}=\sum_{E=E 2}^{E 3} S(E)-K_{3} *\left[\sum_{E=E 1}^{E 2} S(E)+\sum_{E=E 3}^{E 4} S(E)\right]
$$

with

$$
K_{3}=\frac{\sum_{E=E 2}^{E 3} S_{b k g}(E)}{\sum_{E=E 1}^{E 2} S_{b k g}(E)+\sum_{E=E 3}^{E 4} S_{b k g}(E)}
$$

$E_{1}, E_{2}, E_{3}$, and $E_{4}$ represent the limiting energy ranges of the windows. Because of the positioning of background windows on each side of the photopeak window, the threewindow algorithm intrinsically removes background contributions underneath the photopeak even when the nominal slope of the Compton-scatter contributions from higher energy isotopes is changing significantly.

The three-window algorithm was used to extract ${ }^{137} \mathrm{Cs}$ photopeak counts for the YMP survey. The background energy limits that were used to extract the $662-\mathrm{keV}{ }^{137} \mathrm{Cs}$ photopeak count rates were $E_{1}=518, E_{2}=590, E_{3}=734, E_{4}=806$. The extracted isotopic count rates, measured in cps at survey altitude, were converted to soil activity in $\mathrm{pCi} / \mathrm{g}$ by application of a conversion factor which was derived from a radioactive transport matrix model developed by Beck, et al ${ }^{6}$. This method mathematically models the gamma ray flux 
through a detector located at some distance above a source distribution. A brief synopsis of this model is discussed in the next section.

\subsection{Conversion Factors}

Conversion factors have been calculated which relate the measurement photopeak countrate data to the radionuclide activity in the soil. The values are determined by combining a laboratory measurement of the detector efficiency to a given gamma ray energy with a theoretical calculation of the gamma ray flux arriving at the detector as a function of source distribution in the soil.

The unscattered gamma ray flux, $\varphi$, from a point source with activity $S_{0}$ at a distance $r$ from the source is given by

$$
\phi=\frac{S_{o}}{4 \pi r^{2}} e^{-r / \lambda_{a}}
$$

where $\lambda_{a}$ is the gamma ray mean free path in air. This can also be written as

$$
\phi=\frac{S_{o}}{4 \pi r^{2}} e^{-(\mu \rho)_{a} \rho_{a} r}
$$

where

$$
\begin{aligned}
(\mu / \rho)_{a} & =\text { air mass attenuation coefficient, square centimeters per gram }\left(\mathrm{cm}^{2} / \mathrm{g}\right) \\
\rho_{a} & =\text { air density, } \mathrm{g} / \mathrm{cm}^{3}
\end{aligned}
$$

This expression can be expanded to the more general case of a source distributed within the soil. In this case, the unscattered flux of gamma rays of energy $E$ at a height $h$ above a smooth air-ground interface due to an emitter distributed in the soil is given by

$$
\phi=\int_{0}^{\infty} \int_{0}^{\infty} \frac{S_{v}}{4 \pi r^{2}} e^{\left[-(\mu \rho \rho)_{a} \rho_{a} r_{a}\right]} e^{\left[-(\mu \rho)_{s} \rho_{s} r_{s}\right]} 2 \pi x d x d z
$$

where

$$
\begin{aligned}
\mathrm{S}_{\mathrm{v}} & =\text { activity per unit volume, }(\mathrm{\gamma} / \mathrm{sec}) / \mathrm{cm}^{3} \\
r & =r_{a}+r_{\mathrm{s}} \text { in } \mathrm{cm} \\
(\mu / \rho)_{\mathrm{a}},(\mu / \rho)_{\mathrm{s}} & =\text { air and soil mass attenuation coefficients, } \mathrm{cm}^{2} / \mathrm{g} \\
\rho_{\mathrm{a}}, \rho_{\mathrm{s}} & =\text { air and soil density, } \mathrm{g} / \mathrm{cm}^{3}
\end{aligned}
$$


This expression assumes a source distribution which varies only with depth. A uniform distribution in the horizontal plane is also assumed, which leads to results expressed in terms of an averaged value over the FOV of the detector.

The detector response to a given flux, $\varphi$, of gamma rays of energy $E$ incident at an angle $\theta$ can be given in terms of an effective detector area, $A$, defined by

$$
A=\frac{N_{p}}{\phi}
$$

where $N_{p}$ is the net photopeak count-rate, normally given in units of cps. The effective area, in general, varies as a function of the gamma ray angle of incidence and is usually written as

$$
A=A_{0} R(\theta)
$$

where

$$
A_{o}=\text { detector photopeak count-rate for a unit flux incident perpendicular to the }
$$
detector face, $(\mathrm{cps}) /\left(\mathrm{y} / \mathrm{cm}^{2}\right.$-sec).

$R(\theta)=$ ratio of the detector response at an angle $\theta$ to that at $\theta=0^{\circ}$

Combining Equations 10 and 11 with Equation 9 leads to an expression, which relates the measured photopeak count-rate to source activity in the soil. This is given by

$$
N_{p}=\int_{0}^{\infty} \int_{0}^{\infty} \frac{S_{v} A_{0} R(\theta)}{4 \pi r^{2}} e^{\left[-(\mu \rho)_{a} \rho_{a} r_{a}\right]} e^{\left[-(\mu \rho)_{s} \rho_{s} r_{s}\right]} 2 \pi x d x d z
$$

In order to evaluate Equation 12, it is necessary to make some assumptions on the source distribution depth. Three basic types of vertical source distributions are normally encountered in environmental measurements. Naturally-occurring background radiation is normally represented by a uniform volume distribution (i.e., distributed uniformly as a function of depth). Relatively fresh fallout activity is normally represented by a uniform surface distribution (i.e., the radioactivity lies in a thin layer of material on the ground). Fallout activity, which has aged into the soil over a period of time, is most often represented by an exponential distribution of the form

$$
S_{v}=S_{v}^{o} e^{-\alpha z}
$$


where

$$
\begin{aligned}
S_{v}^{o} & =\text { activity per unit volume at the surface, }(\mathrm{y} / \mathrm{sec}) / \mathrm{cm}^{3} \\
\alpha & =\text { reciprocal of the relaxation depth, } \mathrm{cm}^{-1} \\
z & =\text { source distribution depth in the soil, } \mathrm{cm}
\end{aligned}
$$

This implies that the representative volume of soil at a depth of $1 / \alpha$ is assumed to contain approximately 63 percent of the source's total activity. At a depth of $2 / \alpha$ and $3 / \alpha$, respectively, the representative volume of soil is assumed to contain approximately 86 and 95 percent of the total activity.

For the exponential soil depth distribution model, Equation 12 becomes

$$
N_{p}=\frac{S_{v}^{o} A_{o}}{2} \int_{0}^{\pi / 2} \frac{R(\theta) \tan (\theta) e^{\left[-(\mu \rho)_{a} \rho_{a} h \sec (\theta)\right]}}{\alpha+(\mu \rho)_{s} \rho_{s} \sec (\theta)} d(\theta)
$$

This expression relates the measured photopeak count rate, $N_{p}$, to the activity per unit volume at the surface. The detector parameters, $A_{o}$ and $R(\theta)$, are normally obtained empirically for a given system using standard calibration sources. Mass attenuation coefficients for air and typical soils can be found in standard reference tables. An average soil density of $1.5 \mathrm{~g} / \mathrm{cm}^{3}$ and air density of $0.001205 \mathrm{~g} / \mathrm{cm}^{2}$ at $20^{\circ} \mathrm{C}$ are normally assumed, unless actual measured values are available. The detector height, $h$, can be measured in most cases.

In general, it is more useful to relate the photopeak net count-rate data to an average concentration within a given depth, rather than a surface concentration as given in Equation 14. The average concentration in the top $z \mathrm{~cm}$ of soil, $S_{v}(z)$, for a source distributed exponentially with depth is given by

$$
S_{v}(\mathrm{z})=\frac{1}{z} \int_{0}^{z} S_{V}^{o} e^{-\alpha z} d z=\frac{S_{v}^{o}}{\alpha z}\left(1-e^{-\alpha z}\right)
$$

Another result often required is the total activity per unit area. This is given by

$$
S_{A}=\int_{0}^{\infty} S_{v}^{o} e^{-\alpha z} d z=\frac{S_{V}^{o}}{\alpha}
$$


The conversion factors derived for all three source distribution types relate a measured photopeak net count-rate, expressed in units of cps to source activity expressed in units of gamma rays per second $(\mathrm{y} / \mathrm{sec})$ per unit area or unit volume. For a specific isotope, the source activity is normally changed to units of curies or becquerels. The average activityper-unit volume can also be converted to average activity-per-unit mass by dividing $S_{v}^{o}$ by the soil density.

In the above model, the values for " $\alpha$ " and " $z$ ", which were assumed and not measured in the field, are usually poorly known, and are highly dependent upon the actual soil conditions and isotopes present. Also, artificial soil disturbance (farming, construction, etc.) will affect the value of these parameters.

\subsection{Minimum Detectable Concentration}

Since the detectors employed on the aerial system are not shielded, the detector footprint or FOV has no firm boundary. The main factors that define the footprint are the energy of the gamma rays and the attenuation of the gamma rays by the atmosphere. The detector array is thus capable of detecting gamma rays from large distances, but the atmospheric attenuation acts to shield gamma rays from large distances (i.e., "infinite"). The conversion factors used for converting the measured aerial gamma count rate into activity concentrations are based on calculations that assume the radioactivity is uniformly dispersed over an area on the ground that is "large" compared to the FOV of the detector array. Furthermore, the accuracy of the derived conversion factors is also dependent on a specific knowledge of the radioactivity distribution within the soil, specifically the soil depth (assumed to be homogenous to a depth of $2.5 \mathrm{~cm}$ ) and to a lesser extent knowledge of the soil density (assumed to be $1.5 \mathrm{~g} / \mathrm{cm}^{2}$ ), soil moisture content (assumed to be 10 percent) and chemical composition (i.e., a wide range of the naturally occurring radionuclides, such as radioactive potassium and the thorium and uranium decay products). All of these variables are unknown and may vary considerably from the norm (site to site and within each site) due to differences in the terrain (pastures, excavations, rocky culverts, woodlands, facilities, etc.). The calculations also assumed that all daughters are in radioactive equilibrium with their parents, which is not true for the radon daughters.

Since the inferred soil concentration measured by the aircraft is an average over the nominal surface footprint of the detector system, the observed aerial values are a function of both the surface soil concentration and the size of the contaminated surface area. For contaminated surface areas that are not "infinite", significant correction factors must be applied or a larger MDC threshold value needs to be assumed. For instance, an observed measurement just above the cited MDC threshold may imply that the surface activity of part of the detector footprint is at, or even well above, the cited MDC value. Only when the uncorrected, observed, inferred aerial soil concentration is above the cited MDC can one be certain that at least some portion of the detector footprint exceeds the cited MDC threshold value. Thus, for surface activity areas larger than the size of the detector 
footprint, the reported detector activity is nominally equivalent to the surface activity. If the region of surface activity is smaller than the detector footprint, the detector activity related to the surface activity is approximated by the relationship:

$$
(\text { Detector Activity })=(\text { Surface Activity }) *(\text { Activity Area }) /(\text { Footprint Area })
$$

For estimation purposes, the detector footprint radius is approximately the same as the height of the detector (which is its full width at half maximum value), but it is actually somewhat larger (10 to 20 percent, dependent on the gamma photopeak energy of interest). For a detector height or altitude of $150 \mathrm{ft}(46 \mathrm{~m}) \mathrm{AGL}$, the detector's FOV for the aerial detection system is approximately $7,850 \mathrm{ft}^{2}\left(6,570\right.$ square meters $\left[\mathrm{m}^{2]}\right)$. For ${ }^{137} \mathrm{Cs}$, the primary isotope of interest, the system's nominal MDC in pCi/g was calculated to be $0.4 \mathrm{pCi} / \mathrm{g}$ at the 95 percent confidence level for a source distribution size that is equivalent to the above-cited FOV. The MDC was calculated for an altitude of $150 \mathrm{ft} \mathrm{AGL}$, a soil sample depth of $2.5 \mathrm{~cm}$, and an exponential distribution with relaxation depth of $0.33 \mathrm{~cm}$.

As previously mentioned, aerial detection systems provide an "average" over large areas. This average is a result of the limited angular resolution of the detectors and the motion of the aircraft. The angular resolution of the detectors depends primarily on their angular response, air attenuation of the gamma rays in the air and soil, and the detector-source separation distance (i.e., aircraft height over the terrain).

Due to the rugged terrain of the YMP survey, the helicopter was unable to maintain a constant flight altitude of $150 \mathrm{ft}(46 \mathrm{~m})$. The MDC is affected by the altitude AGL. A contour map showing the estimated MDC throughout the survey area is presented in Figure 3 found at the end of the report.

\subsection{Anomaly Verification}

Radioactive decay is a random process. Consequently, any measurement based on observing the radiation emitted is subject to some degree of statistical fluctuation. These inherent fluctuations represent an unavoidable source of uncertainty in all nuclear measurements and often can be the predominant source of imprecision or error. The term "counting statistics" includes the framework of statistical analysis required to process the results of nuclear measurements and to make predictions about the expected precision of quantities derived from these measurements. In a typical nuclear measurement, such as in an aerial survey where data is collected once every second, counting statistics can be used to predict the inherent statistical uncertainty in a single measurement and to provide an estimate of the sample variance to be expected if the measurement were to be repeated many times. The square root of the sample variance would be a measure of the typical deviation (sigma $[\sigma]$ ) of any one measurement from the true mean value, $\bar{x}$, and thus would serve as an indication of the degree of precision for that measurement. However because only a single measurement was acquired, the sample variance $\left(\sigma^{2}\right)$ cannot be calculated directly and must be estimated by analogy with an appropriate statistical model. 
For this aerial survey, the number of measurements is large ( 250,000 samples) and the values of adjacent measurements are not greatly different from each other. In other words, the distribution is slowly varying, and as a continuous function, can be assumed to be a Gaussian (or normal) distribution. If plotted, the distribution is roughly centered about its true mean value $(\bar{x})$, where any asymmetry of the distribution is evidence of an anomaly that would require further evaluation by means of gamma spectral examination. The size of the standard deviation $(\sigma)$ gives some indication of the width of the distribution or the amount of scatter (uncertainty) predicted by the distribution. The range of values $(\bar{x} \pm \sigma)$ will contain the true mean value $(\bar{x})$ of the measurement with an 84.1-percent probability. However, for aerial surveys and the highly variable nature of the background gamma radiation, a variance of one standard deviation is too small to be used to accurately identify any anomalous behavior or patterns within the distribution.

For aerial and ground-based gamma radiation surveys, the " $3 \sigma$ " (99.87 percent probability) criteria test has proven to be, and is widely accepted for, ascertaining the location of widely distributed contamination (i.e., a non-point source). The " $6 \sigma$ " test is primarily used to pinpoint and confirm the location of any isolated, individual point sources. Although the " $3 \sigma$ " test is routinely used, there is still a small probability $(0.13$ percent or $\sim 2,825$ out of 250,000 events) that the reported/detected low-value ( $3 \sigma$ to $4 \sigma$ ) anomaly may be only "statistical" and not representative of the radioisotope in question. Caution needs to be exercised when evaluating any observed anomalies in the data. Anomalies detected over several adjacent or contiguous sampling points with values $>4 \sigma$ are deemed to be genuine, whereas single-point anomalies with values $<6 \sigma$ may be only statistical. In such cases, these possible "false-positive" anomalies will need to undergo gamma spectral examination where a background-subtracted gamma spectrum will be made and evaluated to reveal either the radioisotope of interest, excess levels of natural background radiation, or a smoothly varying background with no discernable peaks. 


\subsection{RESULTS}

The primary purpose of the survey was to identify any significant areas of volumetric manmade radiological contamination in the soil within the YMP proposed land withdrawal area. To accomplish this task, the aerial survey measured and mapped the natural and manmade gamma radiation emanating from within the survey area, and reported any areas that exhibited elevated levels of terrestrial exposure rate, and man-made or isotopic gamma radiation activity (specifically for ${ }^{137} \mathrm{Cs}$ ).

Radiation isopleth contour maps of the terrestrial gamma exposure rate and the activity or count-rates due to the non-naturally-occurring gamma sources of radiation (i.e., ${ }^{137} \mathrm{Cs}$ ) were generated. ${ }^{137} \mathrm{Cs}$ activity was detected at sites associated with NRDS operations and at one site that was previously unknown. The maps in this report include these sites as references for elevated ${ }^{137} \mathrm{Cs}$. In addition, these NRDS sites were included since detectable ${ }^{137} \mathrm{Cs}$ activity (above worldwide fallout) within the YMP survey area was postulated to originate from these sites. No other man-made radioactive material was identified in the survey.

\subsection{YMP Soil Samples}

Soil sample data provided by YMP personnel are plotted on the YMP aerial survey map (see Figure 4 found at the end of the report).

\subsection{Survey Flight Lines}

Actual helicopter flight lines are presented in Figure 5 (found at the end of the report). With the exception of the small area near the Bare Reactor Experiment-Nevada tower, the planned full-ground coverage was achieved. Support cables for the BREN tower presented a flight hazard.

\subsection{RADAR Altimeter}

Of the 249,601 reported data points, 76.75 percent were within the altitude range of 100-200 ft, 13.50 percent were within 200-300 ft, and 10.75 percent were outside of these ranges. As can be seen from the RADAR Altimeter Map (see Figure 6 found at the end of the report), most of the values which were outside the normal 100-200 $\mathrm{ft}$ were in the rugged northern area of the YMP survey.

\subsection{Altitude Profile Data}

Data measured by the aerial system needs correction to account for non-terrestrial contributions (airborne radon, cosmic, aircraft background) and altitude variations. In order 
to properly characterize these contributions, a test line is chosen near the survey area. The test line must be uniquely identifiable from the air to allow repeated precision tracking of the line without navigation aids. It must have relatively uniform radiation properties over an extent larger than the detection footprint. Test line elevation changes must be gradual to allow the aircraft to maintain relatively constant distance AGL.

At the beginning of the survey, the chosen test line was flown at a number of different nominal altitudes. With these data sets, statistical analyses were utilized to extract nonterrestrial background for the test line, the altitude correction coefficient (air mass attenuation), and the corrected terrestrial activity profile for the test line. For all following flights, the test line was flown at survey altitude before and after every flight. The per-flight data were altitude-corrected and the background necessary to normalize the average test line value to the value predetermined from the altitude profile was applied to the pre- and post per-flight test lines. Finally, notated plots of the per-flight data with appropriate background information were provided to YMP for quality assurance purposes.

Plots of the altitude profile data (Figures 7 and 8 ) follow. Figure 7 shows the uncorrected gross count data as measured in flight. The $x$ axis units are $\mathrm{ft}$ along the test line in the survey coordinate system. The y axis units are uncorrected counts per second. Starting at the highest count-rate trace, the nominal flight altitudes were 100,150, 300, 500, 1,000, and 3,000 ft AGL. Because of the altitude differences, the observed count rates are significantly different. Using the average observed count rates from the altitude profile data; background, altitude coefficient, and net test line count rates were extracted for use in correcting YMP survey flight data. Figure 8 is a "proof plot" of the altitude profile data after being corrected to $150 \mathrm{ft} \mathrm{AGL}$ (the nominal survey altitude) utilizing the derived background and altitude coefficients. Note that the 3,000-ft data were not corrected/plotted. Its purpose was to aid in determining the nominal background of the test line. At 3,000 ft, only 0.7 percent of the terrestrial activity that would be seen at $150 \mathrm{ft}$ is present. The $3,000-\mathrm{ft}$ value was used as a seed value for the iterative process required to extract the desired parameters from the lower altitude profile data. The correction is very effective over the nominally flat test line terrain. Because the radar altimeter sees a very small footprint and the detection footprint is considerably larger, altitude corrections over the very rugged mountainous terrain in the northern part of the YMP survey are not as precise as over the relatively flat test line. 


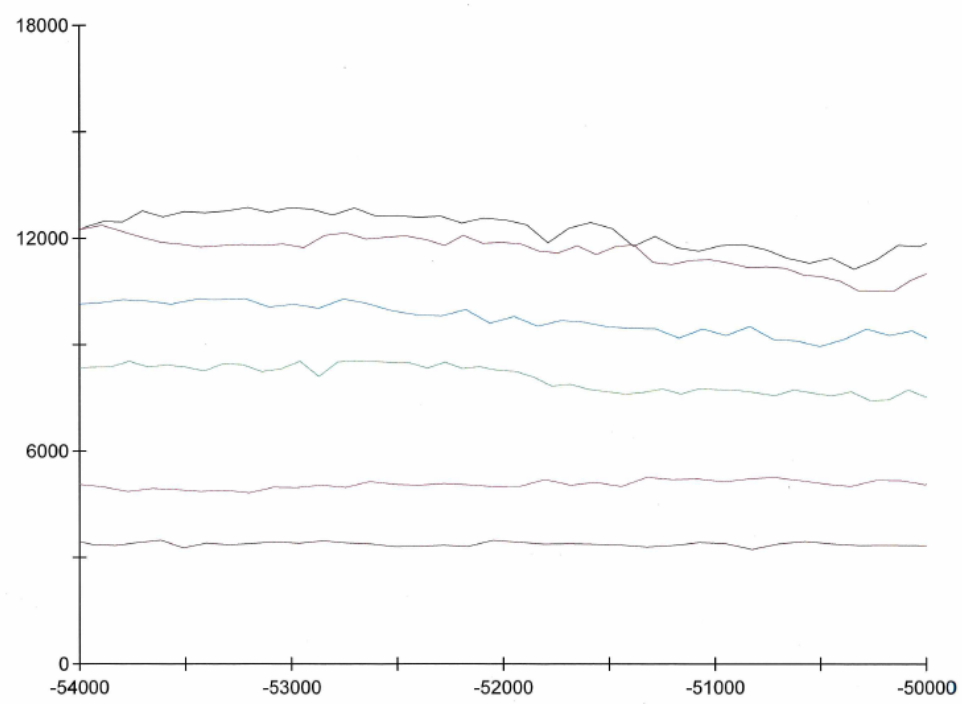

Figure 7. Altitude Profile Data, Uncorrected for Background and Altitude

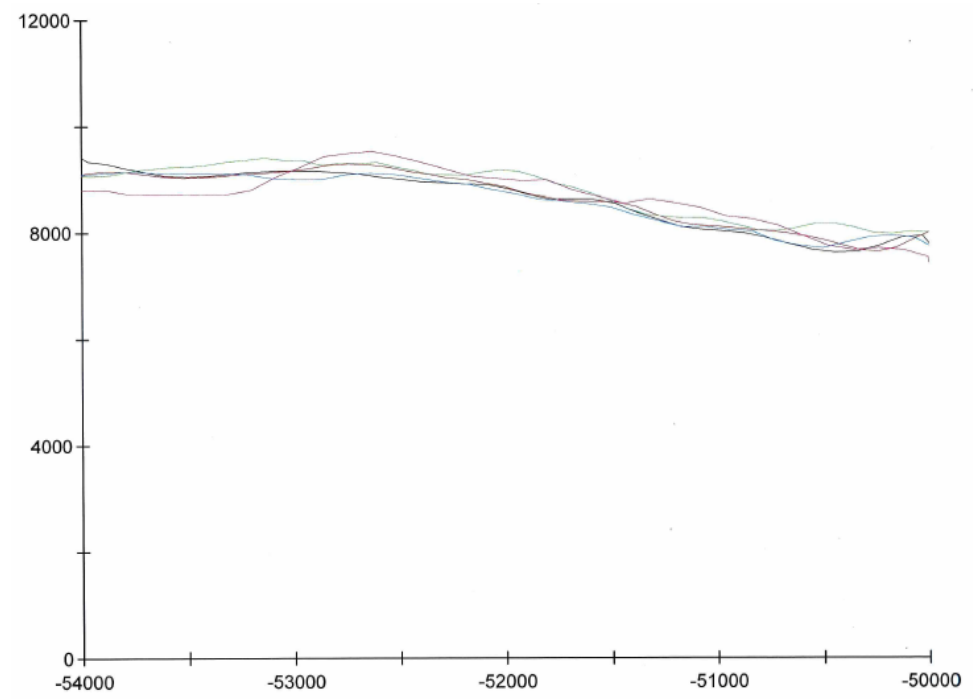

Figure 8. Altitude Profile Data, Corrected for Background and Altitude 


\subsection{Terrestrial Exposure Rate}

The terrestrial gamma exposure rates inferred from the aerial radiological data are shown as a contour map superimposed on a USGS map image (color-coded contours with designators) shown in Figure 9 (found at the end of the report). The exposure rate information was corrected for background and altitude variations. The exposure rates are expressed in units of $\mu \mathrm{R} / \mathrm{h}$ at a height of $1 \mathrm{~m} \mathrm{AGL}$. Cosmic-ray contributions (nonterrestrial), ranging in value from 4.3 to $7.0 \mu \mathrm{R} / \mathrm{h}$ at nominal elevations above sea level of 2,500 to $6,600 \mathrm{ft}$, are not included in this figure.

The inferred aerial exposure rates are relatively uniform and represent normal fluctuations in the natural background radiation. The exposure rates were observed to vary primarily between 3 to $22 \mu R / h$.

Exposure rates observed in the western and northern portion of the survey area tended to be somewhat greater than those observed elsewhere. The inferred YMP exposure rates are well within the range found throughout the contiguous United States, Hawaii, and Alaska ${ }^{7}$. Typical gamma energy spectra of natural background gamma radiation within the YMP survey are shown in Figure 8. Note that only natural photopeaks are discernible.

\subsection{Terrestrial Exposure with Serpentine Normalization Layer}

The base layer for the figure is the terrestrial exposure rate contour map (see Figure 10 found at the end of the report). Overlaid on this map are the color-coded serpentine exposure rate points. In most areas, the data points are not visible since they are the same color (i.e., same exposure rate range) as the underlying contour map. White-lined segments indicate the actual aircraft flight path during the serpentine flight. In those few areas where the serpentine and contour values are different, crescent-shaped points appear centered on the white serpentine line.

\subsection{Minimum Detectable Concentrations Illustrations}

Data shown in Figure 11 were taken from a flight line segment over the area designated as $\mathrm{ID}=\# 5$ (Test Cell A Facility). The $\mathrm{x}$-axis is in $\mathrm{ft}$ in the survey steering system. Three data traces are presented. The trace with the large positive excursion is the aerial implied $\mathrm{pCi} / \mathrm{g}$ concentration. This trace is bracketed by the running MDC positive and negative traces. Note that the implied concentration values which are in regions where no excess contamination above worldwide fallout levels exists (that is, before and after the peak excursion) are never exactly zero in value, but fluctuate about the zero axis in a statistical manner. 


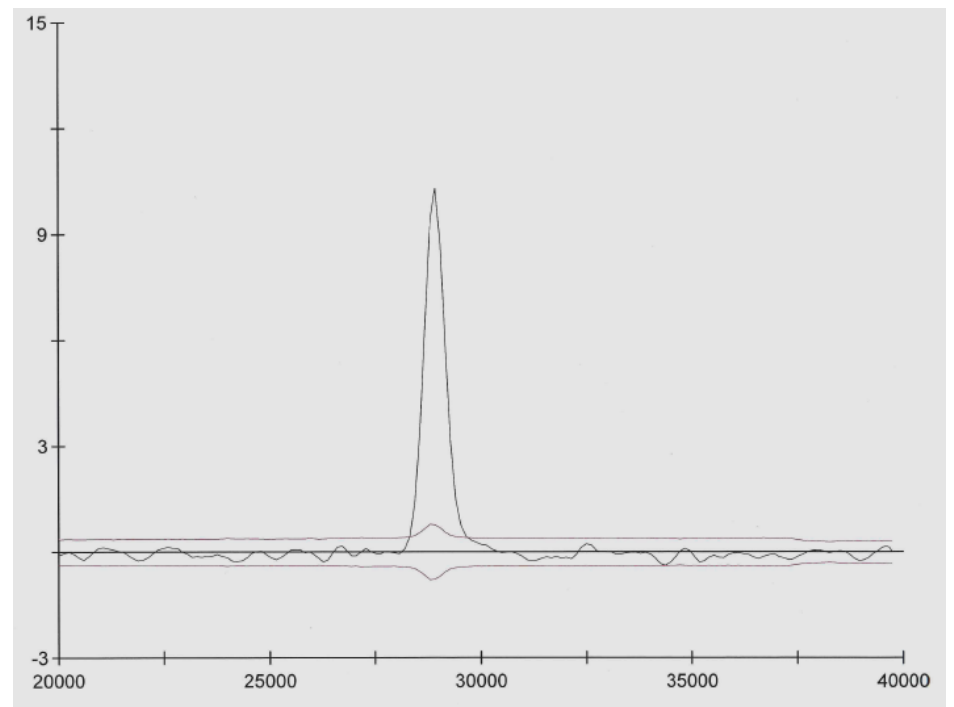

Figure 11. Line Segment from YMP Survey over ID $=\# 5{ }^{137} \mathrm{Cs}$ Area

Figure 12 is a distribution diagram for the entire YMP survey. The $x$-axis is in $\mathrm{pCi} / \mathrm{g}$; the $y$-axis is in number of occurrences per $0.04 \mathrm{pCi} / \mathrm{g}$ data bin. The central trace, nominally centered about zero, is the distribution of all pCi/g values (most of which are background) measured for the entire survey. The running MDC distributions, of nominal statistical value 3 sigma, bracket the central value. For mapping purposes, the first level of the $\mathrm{pCi} / \mathrm{g}$ map was set at $0.4 \mathrm{pCi} / \mathrm{g}$; the most likely value of MDC at the 3 sigma confidence level. Because the extraction/background removal is a statistical process, it should be recognized that there will be a small number of background values which will overlap into the MDC distribution to create "false positives" as well as some real values at low activity that will be missed.

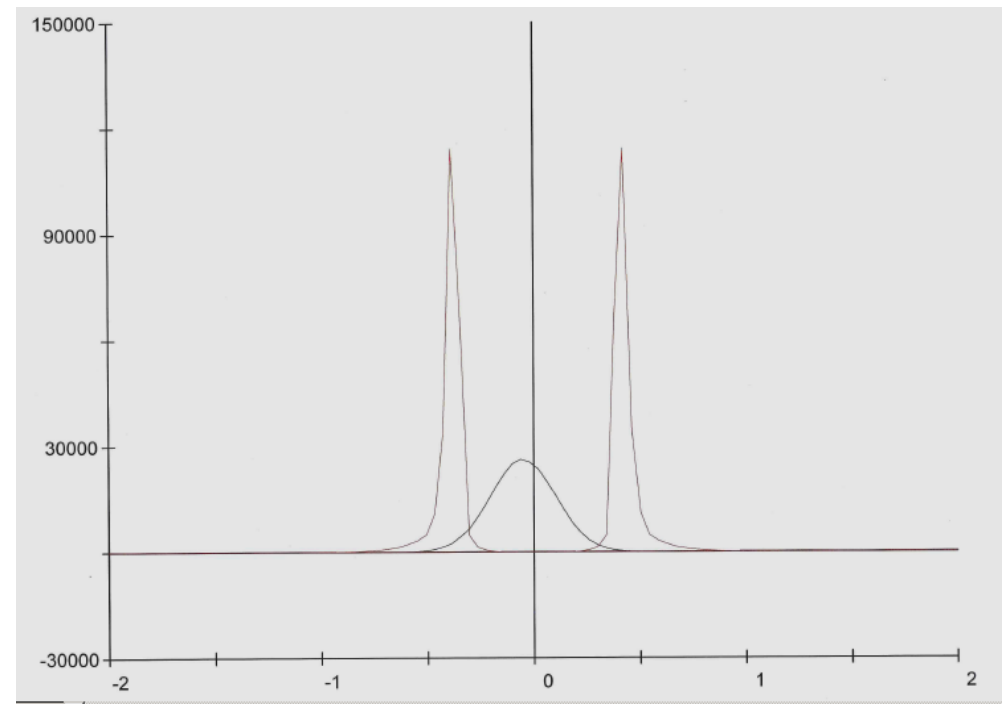

Figure 12. Distributions of pCi/g and MDC Values. YMP Full Survey 
Moving the MDC distribution to a most likely value of 0.8 ( $\sim 6$ sigma) would essentially eliminate false positives but would miss low level real positives by completely separating the background distribution from the MDC distributions. Conversely, moving the MDA to a most likely value of 0.2 ( 1.5 sigma) would pick up more real low-level positives, but would create a large number of false positives because of the overlap of the background distribution with the MDC distributions. The chosen MDC distribution limits at 3 sigma represent a compromise, which balances these uncertainties.

\section{$6.8 \quad{ }^{137}$ Cs Volumetric Concentration Map}

Plotted volumetric concentration values assume a uniform near-surface deposition over the full aerial detector footprint as well as an exponential depth distribution in the soil (see Figure 13 found at the end of the report). Such conditions occur in areas subject to fallout conditions (Chernobyl, above-ground testing, etc.) and subsequent weathering which migrate material into the soil.

Of the five ${ }^{137} \mathrm{Cs}$ locations noted on this plot, only Location 1 appears to be a soil site. With the exception of the five NRDS locations, no ${ }^{137} \mathrm{Cs}$ soil concentrations above the local MDC were apparent. The five NRDS locations are identified on the cesium map as Locations 1 through 5. Their identities are as follows:

1) Vicinity of Well J-11

2) Radioactive material containers outside the Area 25 Radioactive Material Storage Facility (RMSF) storage yard

3) Nuclear Furnace car within the Area 25 RMSF storage yard

4) Test Cell C Facility, and

5) Test Cell A Facility.

Four of those locations were known to be NRDS-contaminated equipment storage facilities or testing support that existed at the time of the survey flyover. Activity at these locations was expected. They do not correspond to contaminated surface soil areas. Location 1 was the exception and required further investigation. The aerial survey identified ${ }^{137} \mathrm{Cs}$ at Location 4 just south of the Well J-11 located within Area 25 of the NTS. The presence of ${ }^{137} \mathrm{Cs}$ was unexpected since no radiological operations had been documented to have occurred near the well. NTS Radiological Control personnel were notified and dispatched to conduct additional surveys of the anomalous area. Their surveys indicated an impacted area of approximately $30 \times 10 \mathrm{~m} .{ }^{137} \mathrm{Cs}$ was confirmed as the only man-made radiological contaminant present. 


\section{9 $\quad{ }^{137}$ Cs Minimum Detectable Volumetric Concentration}

Minimum detectable activity is dependent on observed count rates which in turn are a function of flight altitude. Figure 3 (found at the end of this report) shows the nominal variation of MDC over the YMP survey area. With the exception of the five NRDS locations, no ${ }^{137} \mathrm{Cs}$ soil concentrations above the local MDC were apparent. For the full survey, 54.8 percent of the points measured had MDC values less than $0.4 \mathrm{pCi} / \mathrm{g}$ and 44.2 percent were in the range 0.4 to 0.7 . The 1 percent remaining had MDC values from 0.7 to 2.2 (most of these were in the rugged terrain in the northern region of the survey area.

\subsection{Typical Survey Spectra from Background Areas}

Note that in Figures 14 and 15, the background spectral shapes are very similar even though the total activity is quite different. This is the property of background spectra which enables the effective use of three-window and other spectral extraction techniques.

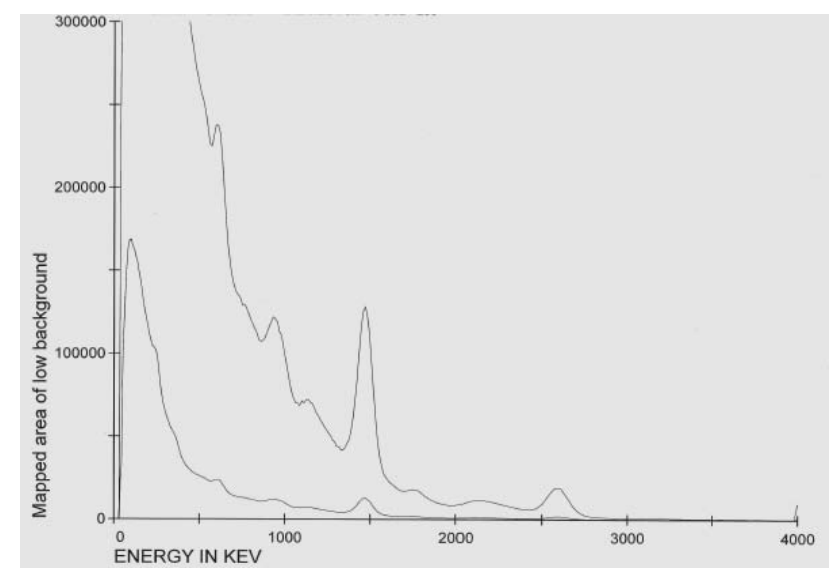

Figure 14. Low Typical Background Area (9.7 $\mu R / h)$

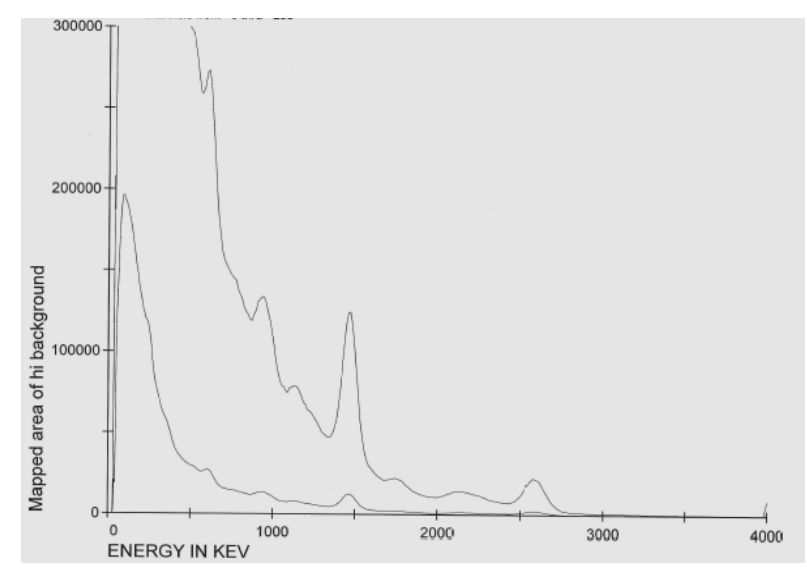

Figure 15. High Typical Background Area (12.3 $\mu \mathrm{R} / \mathrm{h})$ 


\subsection{Areas Where Cesium-137 Was Detected}

Of the five areas where cesium was detected (all in the NRDS area, none in the YMP withdrawal area), only ID \#1 was found to have ${ }^{137} \mathrm{Cs}$ distributed in soil. The other four areas had ${ }^{137} \mathrm{Cs}$ in containers, facilities, or distributed in paved areas. Although volumetric $\mathrm{pCi} / \mathrm{g}$ values do not apply to such non-soil areas, they do indicate relative cesium activity in such areas.

A cursory investigation of ID \#1 by BN Radiological Control personnel estimated an affected area on the ground of approximately $300 \mathrm{~m}^{2}$. With a detector field of view $300 \mathrm{ft}$ in diameter $\left(\sim 6,570 \mathrm{~m}^{2}\right)$ and a soils area of $\sim 300 \mathrm{~m}^{2}$, the reported volumetric concentration in ID \#1 soil may be underestimated by the aerial system by a factor of $\sim 22(6,570 / 300)$.

Table 1. Areas of ${ }^{137}$ Cs Detection

\begin{tabular}{|c|l|l|l|}
\hline ID & \multicolumn{1}{|c|}{ Latitude (deg) } & \multicolumn{1}{|c|}{ Longitude (deg) } & \multicolumn{1}{c|}{ Comments } \\
\hline 1 & 36.78462 & -116.28534 & Vicinity of Well J-11 \\
\hline 2 & 36.81985 & -116.29736 & $\begin{array}{l}\text { Radioactive material containers } \\
\text { outside Area 25 RMSF storage } \\
\text { yard }\end{array}$ \\
\hline 3 & 36.81974 & -116.29309 & $\begin{array}{l}\text { Nuclear Furnace Car within the } \\
\text { Area 25 RMSF storage yard }\end{array}$ \\
\hline 4 & 36.83021 & -116.27594 & Test Cell C Facility \\
\hline 5 & 36.82934 & -116.25736 & Test Cell A Facility \\
\hline
\end{tabular}

\subsection{Cesium-137 Extraction Over Test Cell C}

Figure 16 shows a background spectrum summed for 1.049 minutes ( 63 data points) in the vicinity of Test Cell $\mathrm{C}$. The only points accepted into this spectrum had $\mathrm{pCi} / \mathrm{g}$ values less than the MDC. Note the single photopeak present at $\sim 609 \mathrm{keV}$ (natural bisimuth-241 $\left.\left[{ }^{214} \mathrm{Bi}\right]\right)$.

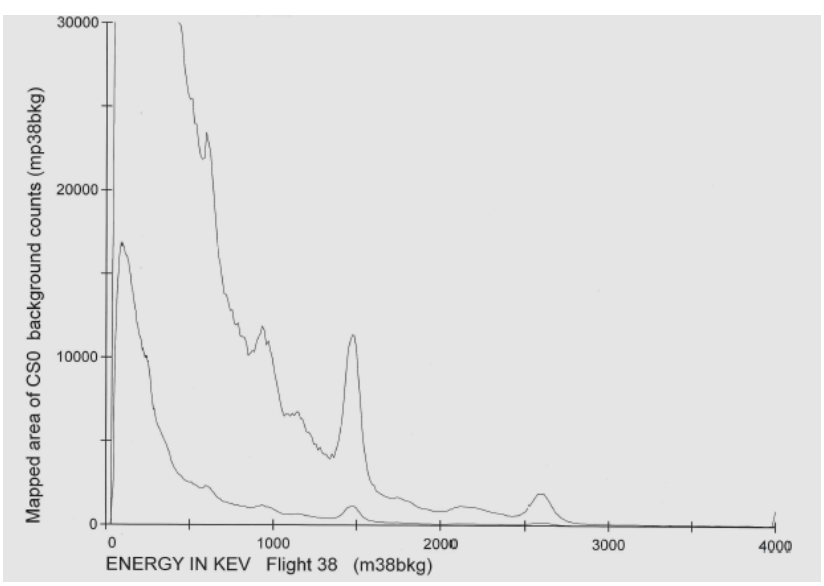

Figure 16. Background Spectrum Near Test Cell C 
Figure 17 shows a gross spectrum summed for 0.82 minutes ( $\sim 50$ data points) directly over the Test Cell $\mathrm{C}$ area, which indicated ${ }^{137} \mathrm{Cs}$ on the $\mathrm{pCi} / \mathrm{g}$ map. The only points accepted into this spectrum had $\mathrm{pCi} / \mathrm{g}$ values greater than the MDC. Note the two photopeaks present at $\sim 609 \mathrm{keV}$ (natural ${ }^{214} \mathrm{Bi}$ ) and $\sim 662 \mathrm{keV}\left({ }^{137} \mathrm{Cs}\right.$ ).

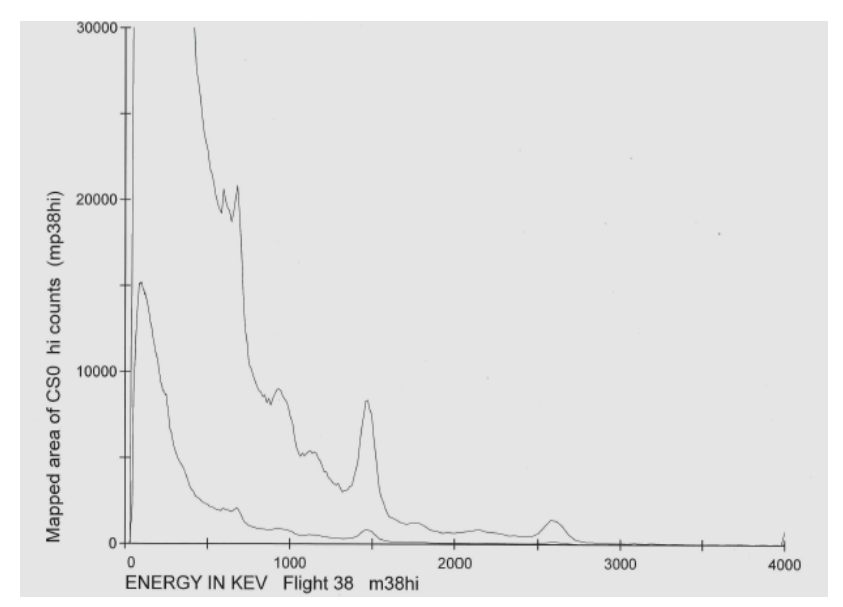

Figure 17. Gross Spectrum over Test Cell C

Figure 18 is a net spectrum produced by subtracting Figure 16 background, normalized by counts in the spectrum above ${ }^{137} \mathrm{Cs}$ photopeak energies, from the Figure 17 gross spectra. The net spectrum unquestionably confirms the presence of ${ }^{137} \mathrm{Cs}$ over Test Cell $\mathrm{C}$. While the ${ }^{137} \mathrm{Cs}$ peak might be missed in the Figure 17 gross spectrum plot, ${ }^{137} \mathrm{Cs}$ is clearly evident in the extracted net spectrum of Figure 18.

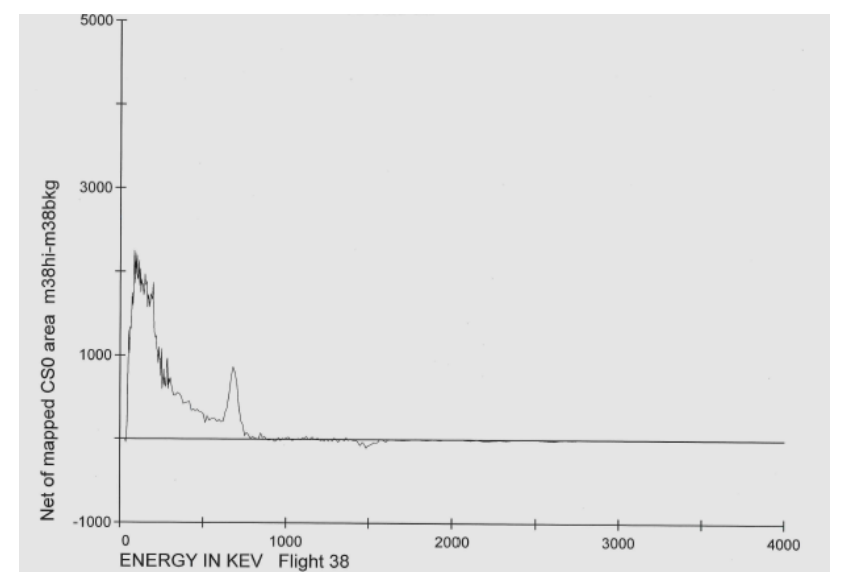

Figure 18. Net Spectrum over Test Cell C (Figure 17 Gross Minus Figure 9 Background) 


\subsection{CONCLUSION}

An aerial radiological survey of the YMP proposed land withdrawal area and adjacent NTS/NRDS facilities was conducted from January to April 2006. The aerial survey was flown at a nominal altitude of $150 \mathrm{ft}(46 \mathrm{~m}) \mathrm{AGL}$. Terrestrial exposure rates over the majority of the survey area were due to the natural background gamma radiation and ranged from 3 to $22 \mu \mathrm{R} / \mathrm{h}$. This is well within the range found throughout the contiguous United States, Hawaii, and Alaska. The nominal cosmic contribution (4.3 to $7.0 \mu \mathrm{R} / \mathrm{h}$ at 2,500 to 6,500 feet MSL) is not included.

Five locations were identified as containing the presence of elevated levels of radioactivity. ${ }^{137} \mathrm{Cs}$ was confirmed as the only man-made radiological contaminant present. All five locations were in the NRDS area; none were within the YMP withdrawal area.

It should be noted that no excess levels of ${ }^{234} \mathrm{Th},{ }^{234} \mathrm{U}$, or ${ }^{235} \mathrm{U}$ had been detected. Neither has any other significant (nonstatistical) man-made radiation activity been detected within the remainder of the survey area. The same can be said for the area along the special lowaltitude flight conducted over the three drainage areas and alongside the three major power lines.

In summary, no significant areas of surface radiological contamination were found within the YMP proposed land withdrawal survey area. The ${ }^{137} \mathrm{Cs}$ levels reported for this survey do not exceed the typical fallout distribution reported for most areas of the continental United States ${ }^{8}$. 


\subsection{REFERENCES}

1. Colton, D. An Aerial Radiological Survey of the Area Surrounding and Encompassing the Rocky Flats Environmental Technology Site, Jefferson County, Colorado, Survey Dates: June 12 to 15, 2005. Report No. DOE/NV/11718--1153, December 2005; Bechtel Nevada, Las Vegas, Nevada.

2. Colton, D. A Series of Low-Altitude Aerial Radiological Surveys of Selected Regions Within Areas 3, 5, 8, 9, 11, 18 and 25 at the Nevada Test Site, Report No. DOE/NV/11718-362, December 1999, Bechtel Nevada, Las Vegas, Nevada.

3. Proctor, A. E. Aerial Radiological Surveys. Report No. DOE/NV/11718-127, 1997; Bechtel Nevada, Las Vegas, Nevada.

4. Hendricks, T. J. "Radiation and Environmental Data Analysis Computer (REDAC) Hardware, Software, and Analysis Procedures" in Remote Sensing Technology, Proceedings of a Symposium on Remote Sensing Technology in Support of the United States Department of Energy, 23-25 February, 1983. Report No. EGG-10282-1057, 1985; EG\&G, Las Vegas, Nevada.

5. Hendricks, T. J. and S.R. Riedhauser. An Aerial Radiological Survey of the Nevada Test Site, Survey Dates - August to September 1994, Report No. DOE/NV/11718-324, December 1999, Bechtel Nevada, Las Vegas, Nevada.

6. Beck, H., J. DeCampo, and C. Gogolak. InSitu Ge(Li) and Nal(TI) Gamma Ray Spectrometry. Report No. HASL-258; 1972; U.S. Atomic Energy Commission Health and Safety Laboratory, New York, New York.

7. Lindeken, C. L., K. R. Peterson, D. E. Jones, and R. E. McMillen. "Geographical Variations in Environmental Radiation Background in the United States" in Proceedings of the Second International Symposium on the Natural Radiation Environment, August 7-11, 1972, Houston, Texas. Available from the National Technical Information Service, Springfield, Virginia; pp 317-332.

8. Mohr, R.A. and L.A. Franks. Compilation of ${ }^{137}$ Cs Concentrations at Selected Sites in the Continental United States. Report No. EGG-1183-2437 (Revised), 1982, EG\&G, Goleta, California. 


\section{APPENDIX A. AERIAL SURVEY PARAMETERS}

Survey Site

Survey Location

Survey Dates

Survey Altitude

Average Ground Speed

Line Spacing

Number of Survey Lines

Navigation System

Line Direction

$\mathrm{Nal}(\mathrm{T} /)$ Detector

Configuration

Acquisition System

Aircraft

Mission Scientist

Data Scientist

Data Analyst
Yucca Mountain Proposed Land Withdrawal

Nye County, Nevada

January 25 - April 19, 2006

nominal $150 \mathrm{ft}(46 \mathrm{~m})$ above ground level (AGL)

70 knots (36 meters per second $[\mathrm{m} / \mathrm{s}]$ )

$250 \mathrm{ft}(76 \mathrm{~m})$

386

Trimble Differential Global Positioning System (DGPS)

North-South (nominally parallel with the rugged [highly variable] mountainous terrain features)

Twelve 2- x 4- x 16-in. (5- x 10- x 41-cm logs

Radiation and Environmental Data Acquisition and Recorder, Version V (REDAR V)

Bell-412 Helicopter

Tail Number: N411DE

Craig Lyons

Thane Hendricks

Jezabel Stampahar 


\section{APPENDIX B. FLIGHT SUMMARY TABLE}

\begin{tabular}{|c|c|c|c|}
\hline Date & $\begin{array}{c}\text { Number of } \\
\text { Flights }\end{array}$ & $\begin{array}{c}\text { Number of } \\
\text { Lines }\end{array}$ & Comments \\
\hline $1-25-06$ & 2 & 12 & $\mathrm{~N} / \mathrm{A}$ \\
\hline $1-26-06$ & 2 & 16 & $\mathrm{~N} / \mathrm{A}$ \\
\hline $1-30-06$ & 2 & 12 & N/A \\
\hline $1-31-06$ & 2 & 30 & $\begin{array}{l}22 \text { short lines included due to high winds over } \\
\text { YMP. }\end{array}$ \\
\hline $2-01-06$ & 3 & 38 & $\begin{array}{l}\text { Completed survey lines over portal area after } \\
\text { YMP radioactive sources were secured } \\
\text { underground. }\end{array}$ \\
\hline $2-02-06$ & 3 & 24 & N/A \\
\hline 2-06-06 & 2 & 12 & N/A \\
\hline 2-07-06 & 2 & 13 & $\mathrm{~N} / \mathrm{A}$ \\
\hline $2-08-06$ & 3 & 16 & $\begin{array}{l}\text { High winds over Shoshone peak limited to one } \\
\text { survey line for first flight. Moved survey to } \\
\text { western boundary and flat terrain. }\end{array}$ \\
\hline $2-09-06$ & 3 & 21 & $\begin{array}{l}\text { Continue survey over flat terrain on west side } \\
\text { due to high winds over ridges. }\end{array}$ \\
\hline 2-13-06 & 3 & 18 & Continue surveys on west side due to winds. \\
\hline $2-14-06$ & 3 & 22 & $N / A$ \\
\hline $2-16-06$ & 2 & 16 & $\begin{array}{l}\text { Experienced a stand-down until March 6, 2006, } \\
\text { due to helicopter maintenance and } \\
\text { unavailability of Desert Rock building. }\end{array}$ \\
\hline 3-06-06 & 2 & 12 & Early stand-down due to high winds. \\
\hline 3-13-06 & 1 & 24 & All short lines on east side of survey area. \\
\hline $3-14-06$ & 2 & 34 & $\begin{array}{l}\text { Includes } 26 \text { short lines on east side of survey } \\
\text { area. }\end{array}$ \\
\hline
\end{tabular}




\begin{tabular}{|c|c|c|l|}
\hline Date & $\begin{array}{c}\text { Number of } \\
\text { Flights }\end{array}$ & $\begin{array}{c}\text { Number of } \\
\text { Lines }\end{array}$ & \multicolumn{1}{|c|}{ Comments } \\
\hline $3-15-06$ & 1 & 2 & $\begin{array}{l}\text { Late departure from RSL-N due to tours and } \\
\text { briefings. }\end{array}$ \\
\hline $4-03-06$ & 2 & 6 & High winds over survey area. \\
\hline $4-06-06$ & 2 & 14 & Airspace over YMP closed during afternoon. \\
\hline $4-10-06$ & 2 & 12 & N/A \\
\hline $4-13-06$ & 1 & 8 & N/A \\
\hline $4-18-06$ & 2 & 15 & N/A \\
\hline $4-19-06$ & 2 & 13 & A total of 390 lines were completed. \\
\hline
\end{tabular}

Factors Affecting Survey Schedule:

1. A large fraction of the survey lines included elevation changes from 2,500 to $6,600 \mathrm{ft}$ over the length of the survey line (approximately 30 miles [mi]). The mountainous terrain of Yucca Mountain itself and the Pinnacles Ridge area have localized wind fields that exceeded the criteria for the pilots to complete the survey lines safely. Alternative survey lines over flatter terrain were used when possible.

2. The weather pattern at the start of the surveys in late January was relatively benign. However, the survey area and Desert Rock were impacted with significant winter weather systems from late February through late March. These systems routinely generated wind speeds exceeding the 20 miles per hour ( $\mathrm{mph}$ ) safety basis of the work plan.

3. The REDAR system and the GPS units experienced some shutdowns during preflight checks and occasionally during the survey flights due to hardware and software problems. Troubleshooting the systems did affect the survey schedule on some days; however, the equipment was repaired at Desert Rock in all cases.

4. Other higher priority tenants occupied the building in late February, which did not allow YMP flight operations to deploy from Desert Rock.

5. The airspace over the survey area was restricted by either competing aerial flights or an NTS Area 25 facility or project operation over flight restriction. The airspace restrictions were generally scheduled in advance, but this still created some challenges to find alternative survey lines, or caused standdowns near the end of the project when alternatives were limited. 
The conversion factors used for converting the measured aerial gamma count-rate data into activity concentrations are based on calculations that assume that the radioactivity is uniformly dispersed over an area on the ground that is "large" compared to the field of view of the detector array. Furthermore, the accuracy of the derived conversion factors is also dependent on a specific knowledge of the radioactivity distribution within the soil, specifically the soil depth (assumed to be homogenous to a depth of 2.5 centimeters), and to a lesser extent knowledge of the soil density (assumed to be 1.5 picocuries per gram [pCi/g], soil moisture content (assumed to be 10 percent) and chemical composition (i.e., a wide range of the naturally-occurring radionuclides, such as radioactive potassium and the thorium and uranium decay products). All of these variables are unknown and may vary considerably from the norm (site to site and within each site) due to differences in the terrain (pastures, excavations, rocky culverts, woodlands, facilities, etc.). The calculations also assumed that all daughters are in radioactive equilibrium with their parents, which is not true for the radon daughters.

Since the inferred soil concentration measured by the aircraft is an average over the nominal surface footprint of the detector system, the observed aerial values are a function of both the surface soil concentration and the size of the surface area. For source surface areas that are not "infinite", significant correction factors must be applied or a larger minimum detectable concentration threshold value is assumed.

For estimation purposes, the detector footprint radius is approximately the same as the detector distance (i.e., height) above the source. For this survey, the ${ }^{137} \mathrm{Cs}$ net count-rate data was converted from counts per second to $\mathrm{pCi} / \mathrm{g}$ for a nominal flight altitude of 150 feet (46 meters) above ground level over an "infinite" source (> 300 feet in diameter). 
Terrestrial Exposure Rate (Gross Count)

Source Energy Window

Conversion Factor

Cosmic Ray Contribution

Air Attenuation Coefficient

${ }^{137}$ Cs Volumetric Activity (pCi/g)

Source Energy Window

Lower Background Window

Upper Background Window

Conversion Factor

MDC (3 sigma)
$38-3026 \mathrm{keV}$

$1729(\mathrm{cps}) /(\mu \mathrm{R} / \mathrm{h})$

4.3 to $7.0 \mu \mathrm{R} / \mathrm{h}$ (elevation dependent) $0.00571 \mathrm{~m}^{-1}\left(0.0015 \mathrm{ft}^{-1}\right)$ 
Figure 3. ${ }^{137} \mathrm{Cs}$ Minimum Detectable Volumetric Concentration (MDC) 
Figure 4. YMP Soil Samples 
Figure 5. Survey Flight Lines 
Figure 6. RADAR Altimer 
Figure 9. Terrestrial Exposure Rate 
Figure 10. Terrestrial Exposure Rate with Serpentine Normalization Layer 
Figure 13. ${ }^{137} \mathrm{Cs}$ Volumetric Concentration 


\section{DISTRIBUTION}

Bechtel SAIC
A. Mitchel
G. Tauss
T. Vaughn

(1)

(1)

(1)

Remote Sensing Laboratory - Nellis

C. Brown

D. Colton

R. Flanagan

T. Hendricks

R. Hopkins

C. Lyons

E. McGlothen

S. Riedhauser

J. Shoemaker

\section{DOE/OCRWM}

R. Spence

\section{NNSA/NSO}

J. Ginanni

R. Thompson

(1)

\section{NNSA/HQS}

D. Bowman

A. Remick

OSTI (electronic copy)

Resource Centers

NNSA/NSO Public Reading Facility NNSA/NSO Technical Library

RSL-Nellis

AN AERIAL RADIOLOGICAL SURVEY OF THE YUCCA MOUNTAIN PROPOSED LAND WITHDRAWAL AND ADJACENT AREAS

NYE COUNTY, NEVADA

DOE/NV/11718--1258

DOE/NV/25946--001

DATE OF SURVEY: January 25 to April 19, 2006

DATE OF REPORT - July 2006 